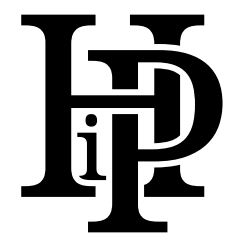

\title{
Piotr OBACZ
}

Uniwersytet Jagielloński, Wydział Studiów Międzynarodowych i Politycznych, Kraków, Polska

\section{Podziały społeczno-polityczne - tezy teoretyczne}

\author{
Socio-political Divisions: Theoretical Theses
}

\section{- Abstrakt •}

Niniejszy artykuł stanowi omówienie założeń teoretycznych, mających zasadnicze znaczenie z perspektywy badań ukierunkowanych na charakterystykę i wyjaśnianie podziałów społeczno-politycznych - ich istoty, struktury, dynamiki i funkcji. Jest to autorska próba, oparta na doświadczeniach badawczych autora nad podziałami społeczno-politycznymi, wyjścia naprzeciw zapotrzebowaniu na skondensowaną wiedzę politologiczną dotyczącą podziałów, mogącą służyć za punkt wyjścia do badań nad tymi fenomenami. Artykuł prezentuje kluczowe tezy teoretyczne na temat podziałów społeczno-politycznych, które warto mieć na uwadze, organizując badania nad podziałami, oraz które powinny być uwzględniane $\mathrm{w}$ procesie formułowania teorii politycznych. Na podstawie tych tez podziały jawią się jako wielowymiarowe zjawiska społeczno-polityczne o procesualnej naturze, mające określone, kontekstualne źródła, swoistą strukturę i cechy, charakter i dynamikę, będące polami znaczeń politycznych, a także wykazujące pewne istotne funkcje względem życia społecznego i politycznego.

Słowa kluczowe: konflikt; podział społeczno-polityczny; teoria polityki

\section{- Abstract •}

The article provides an overview of theoretical assumptions, which are crucial from the perspective of research aiming at characterization and explanation of socio-political divisions - its essence, structure, dynamics, and functions. It is an authorial attempt - based on the author's experiences in the field of research on socio-political divisions - to meet the demand for condensed political science knowledge concerning divisions, which could serve as a starting point for research on these phenomena. The paper presents key theoretical theses on socio-political divisions, which are worth bearing in mind while organizing research on divisions, and which should be taken into account in the process of formulation of political theories. On the basis of the presented theses, divisions appear to be multidimensional socio-political phenomena of processual nature, having certain contextual sources, specific structure and features, character and dynamics, being fields of political meanings, as well as reflecting some important functions to social and political life.

Keywords: conflict; socio-political division; political theory 
Niniejszy artykuł opiera się na treści referatu, który autor wygłosił podczas debaty Polskiego Towarzystwa Nauk Politycznych Oddziału w Płocku (25 marca 2021 r.), poświęconej podziałowi społeczno-politycznemu w Polsce'. Jest to omówienie założeń teoretycznych, mających zasadnicze znaczenie z perspektywy badań ukierunkowanych na charakterystykę i wyjaśnianie podziałów społeczno-politycznych - ich istoty, struktury, dynamiki i funkcji. Ze względu na fakt, że podziały formują się i funkcjonują w różnych kontekstach społecznych, politycznych i strukturalno-państwowych i w związku z tym mogą przybierać różne formy, różna może być ich treść i przejawy. Z uwagi zaś na to, że - wbrew pozorom - wiedza teoretyczna (teoriopolityczna) na temat podziałów jest rozproszona (choć oczywiście nie brakuje opracowań integrujących wiedzę politologiczną w przedmiotowym zakresie), wydaje się potrzebne i uzasadnione przedstawienie w zwięzłej, skondensowanej formie najważniejszych założeń teoretycznych odnoszących się do natury podziałów społeczno-politycznych in genere, z myślą o systematycznych i kompleksowych badaniach politologicznych. Co więcej, dyskurs naukowy i pozanaukowy na temat sytuacji społeczno-politycznej w Polsce skłania do wypowiedzi, które mogą przyczynić się do systematyzacji wiedzy m.in. o rodzimym podziale oraz dać asumpt do pogłębionych badań zarówno empirycznych, jak i z zakresu teorii polityki. Niniejsze opracowanie stanowi autorską próbę wyjścia naprzeciw owemu zapotrzebowaniu na skondensowaną wiedzę politologiczną dotyczącą podziałów społeczno-politycznych, mogącą służyć za punkt wyjścia do badań nad tym fenomenem.

Ze względu na autorski charakter niniejszego omówienia, stanowiącego wypadkową doświadczeń badawczych autora, oraz konwencję polegającą na prezentowaniu w syntetycznej formie tez teoretycznych proponuje się, by literaturę wskazaną na końcu artykułu potraktować jako uzupełnienie tekstu i zarazem inspirację do dalszej lektury, a nade wszystko badań politologicznych.

Różnorakie opisy, ujęcia, koncepcje podziałów są poznawczymi próbami zidentyfikowania, opisu i wyjaśnienia swoistości danego podziału, jego wewnętrznej „logiki”, struktury i mechanizmów funkcjonowania, a nade wszystko, jak się wydaje, są przejawami poszukiwania, woli odkrywania sensu, znaczenia podziałów społeczno-politycznych, a zatem ich wpływu na życie społeczne, relacje polityczne, funkcjonowanie systemu politycznego oraz państwa.

${ }^{1}$ Uprzejmie dziękuję dr. Arkadiuszowi Lewandowskiemu i dr. Marcinowi Polakowskiemu oraz pozostałym Dyskutantom za cenne komentarze, pytania i uwagi przedstawione przez Nich w nawiązaniu do mojego wystąpienia oraz pozostałych wypowiedzi. Przychylny odbiór referatu zainspirował i zachęcił mnie do przygotowania niniejszego zwięzłego opracowania. 
Gdy jako badacze zapoznajemy się z takimi opisami, ujęciami, koncepcjami podziałów, zwłaszcza zaś tymi, które realnie mają status teorii politycznych, i przede wszystkim, gdy prowadzimy badania nad podziałami społeczno-politycznymi, powinniśmy mieć na względzie pewne zasadnicze kwestie - założenia teoretyczne, wywierające znaczący wpływ na to, jak będziemy badać podziały, jak je analizować, opisywać i wyjaśniać. Poniżej zaproponowano pięć takich kwestii - założeń teoretycznych dotyczących podziałów społeczno-politycznych.

1. Podziały są procesami. Podziały należy rozpatrywać jako procesy przebiegające na gruncie praktyki społecznej i politycznej. Czasowy aspekt istnienia podziałów ma tu fundamentalne znaczenie. Podziały to procesy na gruncie praktyki społecznej i politycznej, które trzeba analizować w ich wymiarze czasu przeszłego (formowanie się, rozwój, powstawanie, kształtowanie się), teraźniejszości (bieżące układy relacji, aktualna struktura podziału, dominujące schematy i mechanizmy organizujące życie społeczno-polityczne) oraz przyszłości (przewidywalne implikacje i konsekwencje podziału dla życia społecznego, politycznego oraz dla państwa, kierunki ewolucji podziału i wiążące się z nimi tendencje i zmiany). Ważne zatem, by w badaniach nad podziałami społeczno-politycznymi uwzględniać czas oraz dynamikę, którą w czasie determinują określone relacje społeczno-polityczne.

W tym kontekście warto odnieść się do pewnej kontrowersji, obecnej w debacie publicznej głównie z powodu publicystycznych uproszczeń, a mianowicie: czy podziały społeczno-polityczne mają swój start time - moment początkowy, który niejako rozpoczyna zmiany społeczno-polityczne pod wpływem jakiegoś czynnika „zapłonowego”? Badacze podziałów, empirycy i teoretycy nie mają wątpliwości, że odpowiedź na tak postawione pytanie musi być negatywna. Podziały kształtują się pod wpływem niezwykle złożonych okoliczności i czynników - politycznych, społecznych, ekonomicznych, kulturowych; zasadniczą rolę odgrywa tu m.in. struktura społeczna i wynikające z niej możliwości i oczekiwania społeczne, istniejące instytucje, dominujące wzory relacji i różnorakich zachowań społecznych, postawy, preferencje, zachowania polityczne i wiele innych. Znów mowa tu o trwaniu wszystkich powyższych w czasie - ich trwałość w czasie wpływa na wykształcanie się tego, co nazywamy podziałem, określa jego charakter, determinuje jego funkcjonowanie.

Co więcej, podziały społeczno-polityczne nie rodzą się pod wpływem aktywności jakiejś jednej grupy społecznej, jednostki czy li tylko elity politycznej (elit politycznych). Przeciwnie, podziały są wypadkową złożonych i zinstytucjonalizowanych interakcji społeczno-politycznych, tworzących swoiste wzorce. I właśnie te zinstytucjonalizowane, utrwalone formy relacji społeczno-politycznych powodu- 
ją, że podziały mają określoną strukturę i treść oraz tendencję do „zamrażania się” i odtwarzania na różnych poziomach swego istnienia, wraz ze zmianami różnorakich okoliczności i ewolucją społeczno-politycznych podmiotów.

2. Podziały nie biorą się znikąd. Nawiązując do tego, co napisano powyżej, trzeba powiedzieć, że podziały społeczno-polityczne, jako wynik określonych relacji społecznych trwających w czasie, nie są fenomenami, które powstają niejako „z niczego”, tzn. bez jakichkolwiek wielokierunkowych współzależności podmiotów społecznych i bez szczególnego kontekstu. Każda sytuacja społeczna, proces społeczny, zmiana społeczna „rządzą się” swoimi regułami, wynikającymi ze złożonych uwarunkowań społeczno-polityczno-ekonomiczno-kulturowych - tak też należy rozpatrywać podziały społeczno-polityczne. W badaniach nad podziałami społeczno-politycznymi ważny jest zatem kontekst powstawania i funkcjonowania podziałów - trzeba w tym miejscu podkreślić, że podziały społeczno-polityczne same w sobie są zjawiskami kontekstualnymi.

Warto przy tym pamiętać, że podział nie jest podziałem, gdy nie ma społecznego zakotwiczenia. Jeśli opisując i wyjaśniając rzeczywistość polityczną, za podział możemy uznać każdy dowolny konflikt między partiami politycznymi, to będziemy jedynie - wskutek takiego redukcjonistycznego i zarazem błędnego zabiegu - rozpatrywali jakieś polityczne napięcie czy konflikt między organizacjami i elitami; w takiej sytuacji będziemy mogli mówić co najwyżej o pewnym „polityczno-partyjnym" podziale albo też podziale w łonie elity politycznej czy elity władzy. Podziały wymagają innego podejścia - spojrzenia kompleksowego, uwzględniającego i inkorporującego wymiary: polityczny (organizacyjny), społeczny (empiryczny) oraz aksjologiczno-normatywny (aksjonormatywny).

3. Podziały stanowią pola znaczeń politycznych. $\mathrm{Na}$ swoistą „treść” podziału społeczno-politycznego składają się wszelkie napięcia, wokół których powstał, i kwestie, które organizują relacje społeczno-polityczne w jego ramach, a także reprezentowane przez strony podziału programy, wizje rzeczywistości, popierane przez duże grupy społeczne kierunki polityki i opcje aksjonormatywne, zbiory wartości, symboli, intelektualnych i moralnych punktów odniesienia, różnorakich doświadczeń i ich interpretacji, celów, aspiracji i interesów. Wszystko to powoduje, że podziały społeczno-polityczne same w sobie są zjawiskami sensownymi, ponieważ stanowią złożone systemy sensów społecznych (społeczno-politycznych), wokół których organizują się strony podziału, którym dają one wiarę i przez które podział „wygląda” tak, a nie inaczej. Co więcej, sensowność podziałów społeczno-politycznych wynika już z samego tylko faktu, że są one specyficznymi układami 
współzależności społecznych (społeczno-politycznych) oraz uwarunkowań społeczno-polityczno-aksjonormatywnych (można by tu było oczywiście dodać również: historycznych, ekonomicznych, kulturowych i in.).

\section{Podziały mają nie tylko swoją strukturę, ale mają również swoisty charak-} ter i rytm, by posłużyć się nieco metaforycznymi terminami. Jest do zagadnienie szczególnie interesujące i ważne dla osób badających podziały, ponieważ wiąże się z tym, jak te fenomeny opisywać i wyjaśniać. Bardziej statyczna charakterystyka, ukierunkowana raczej na doraźne próby uchwycenia „obrazu” podziału w danym momencie czasu, jest związana ze skupieniem uwagi badacza na strukturze podziału. Badacz, który zechce skupić się na owym rytmie, podejmie próbę dynamicznego opisu podziału, czy też przedstawienia dynamiki podziału, tj. dynamiki relacji społeczno-politycznych w czasie w obrębie podziału.

Warto przypomnieć, że podział społeczny może nie być odzwierciedlony - czyli reprezentowany - w sferze politycznej, czy też polityczno-partyjnej. Podobnie podziały wewnątrz elity politycznej (elit politycznych) mogą mieć się nijak do sytuacji społecznej. Co więcej, i w sferze społecznej, i w sferze politycznej - obrazowo je rozdzielając - wartości, interesy, koncepcje normatywne, wizje moralne mogą nie być w pełni ukształtowane do tego stopnia, by stanowiły podstawę zorganizowanego działania, mogą też nie być w pełni zrozumiane, uświadomione czy klarownie wyrażone. Niemniej właśnie wtedy, gdy podział społeczny nabiera politycznej reprezentacji; gdy to, co dzieliło elity, zaczyna dzielić także społeczeństwo; gdy to, co było dotąd nieukształtowane czy niewyrażone, staje się obecne w życiu społeczno-politycznym jako element różnicujący dwie lub więcej stron, to wtedy realnie może pojawić się to, co nazwiemy podziałem społeczno-politycznym.

5. Podziały pełnią pewne funkcje. Funkcje te kształtują się samoistnie w toku praktyki społecznej i politycznej i potwierdzają istotność, znaczenie podziałów dla życia społecznego i politycznego oraz funkcjonowania państwa. Choć, jak już powiedziano, podziały są zjawiskami kontekstualnymi, mającymi swoje indywidualne treści i swoiste charaktery, to można dokonać wyszczególnienia takich ogólnych funkcji podziałów in genere. Są to:

a) funkcja integracyjna: podziały integrują ludzi wokół określonych - odmiennych - wizji i programów politycznych, koncepcji moralnych, poglądów i przekonań, a nade wszystko partii politycznych (lub innych organizacji politycznych), które uchodzą za reprezentantów poróżnionych grup/segmentów społeczeństwa. W obrębie podziałów występuje tendencja do tworzenia się i zacieśniania swoistych „wspólnot” - rozległych środowisk społeczno- 
-politycznych o odmiennych wizjach politycznych, celach, dążeniach i politycznych reprezentantach, a więc odmiennych tożsamościach grupowych i politycznych;

b) funkcja mobilizacyjna: podziały, a mówiąc precyzyjnie - to, co jest ich „materią”, oraz związane z tym różnice społeczno-polityczne, napięcia i konflikty, działają mobilizująco w zakresie określonych zachowań politycznych (np. opowiadania się za określonymi partiami i kierunkami polityki oraz promowania pewnych koncepcji aksjonormatywnych, a negowania i odrzucania innych). Funkcja ta daje swój pełny wyraz zwłaszcza w momentach szczególnie poważnych napięć i konfliktów politycznych;

c) funkcja artykulacyjno-reprezentacyjna: podział, poprzez zorganizowaną polityczną aktywność obywateli i ich politycznych reprezentantów, wyraża określone stanowiska aksjonormatywne, promuje określone zbiory rozwiązań i ideologie polityczne. Niejako sam z siebie podział przyczynia się do wyrażenia, ekspresji - artykulacji pewnych stanowisk, interesów, wizji i dążeń, co zachodzi drogą aktywnej politycznej ich reprezentacji. Znaczenie określonych stanowisk, przede wszystkim ich dominacja w przestrzeni publicznej, wynika właśnie z klarownej artykulacji politycznej, dokonywanej przez strony podziału;

d) funkcja strukturyzująca: podział działa porządkująco na relacje społecznopolityczne. To, co nazywamy podziałem społeczno-politycznym, jest w istocie określonym porządkiem, specyficznym ładem społecznym i politycznym, w którym decydującą rolę odgrywają określone segmenty społeczeństwa, określone, reprezentujące je podmioty polityczne, a nade wszystko zasadnicze znaczenie dla owego porządku mają określone ustrukturyzowane i zinstytucjonalizowane, układające się $\mathrm{w}$ pewne schematy relacje między tymi podmiotami społecznymi;

e) funkcja stabilizująca: w ślad za powyższym podziały to zjawiska do pewnego stopnia przewidywalne, tzn. struktura podziału i trwających w jego obrębie relacji społeczno-politycznych czynią to, co dzieje się w ramach podziału w tym specyficznym, poniekąd uporządkowanym układzie, względnie przewidywalnym;

f) funkcja poznawcza: wtórnie podział staje się zrozumiały dla uczestników życia społeczno-politycznego, pomagając im odnaleźć się w rzeczywistości społeczno-politycznej, zaangażować politycznie, uzasadniać wybory polityczne i określone zachowania polityczne.

Fakt, że możemy te funkcje zidentyfikować, jest nie tylko istotnym potwierdzeniem potencjału naukowego politologii, ale ma też fundamentalne znaczenie 
z perspektywy budowania teorii podziałów społeczno-politycznych, ponieważ unaocznia nam to, że te fenomeny społeczno-polityczne, jakimi są podziały, cechują się pewnymi ogólnymi i względnie trwałymi „regułami”, by nie rzec: „prawami”.

Być może jeszcze jedna kwestia wymaga zaakcentowania. Podziały społeczno-polityczne to zjawiska „naturalne” - w tym sensie, że po prostu nieraz powstają w toku życia społecznego, w związku ze złożonymi uwarunkowaniami historycznymi, społecznymi, politycznymi, kulturowymi. Ludzie sobie podobni, członkowie jednego społeczeństwa, narodu, mogą być głęboko poróżnieni - i to jest rzecz, która nie może budzić wątpliwości. Dlatego politolog - i w ogóle każdy badacz społeczny - powinien mieć na uwadze to, że to różnice i odmienności są źródłami polityczności i polityki; wspólnota to ideał lub metafora, różnica to fakt egzystencjalny, mający daleko idące implikacje dla życia społeczno-politycznego, i jest to, jak się wydaje, uwaga wykraczająca poza założenia perspektywy konfliktowej czy agonistycznej. Co więcej, szczególnie ważne w badaniach nad podziałami jest to, by analizując je, zwracać uwagę zarówno na mechanizmy, jakie nimi rządzą, jak i na to, jak strony podziału, a także inni członkowie danego społeczeństwa i instytucje państwa, jeśli zachowują pewną „ponadpodziałową” autonomię, reagują na istniejące różnice. Pozwoli to nie tylko rozpoznać specyfikę danego podziału, ale także ocenić, czy jest on dysfunkcjonalny względem państwa i społeczeństwa, czy działa w jakimś sensie destrukcyjnie, czy też relacje „podziałowe” zachowują swoistą neutralność w zakresie swego oddziaływania na całokształt funkcjonowania państwa i społeczeństwa.

Podziały to wielowymiarowe zjawiska społeczno-polityczne o procesualnej naturze, mające określone, kontekstualne źródła, swoistą strukturę i cechy, charakter i dynamikę, będące polami znaczeń politycznych, a także wykazujące pewne istotne funkcje względem życia społecznego i politycznego. Takie złożone fenomeny są jednymi z najważniejszych dla nauki o rzeczywistości społeczno-politycznej, dla naszej wiedzy o niej; jednocześnie stanowią obiekty badawcze stwarzające wyjątkowe możliwości realizacji potencjału naukowego politologii. Podobnie jest w przypadku teorii polityki, immanentnej części politologii. Dla teoretyków polityki podziały społeczno-polityczne to obiekty, które jak w soczewce skupiają wszystkie zagadnienia, które badaczy interesują, od istoty polityczności i polityki do wzorców zachowań społeczno-politycznych w określonych warunkach itd.; jednocześnie teorie podziałów społeczno-politycznych mają zasadnicze znaczenie dla wiedzy politologicznej. 
Niniejszy artykuł miał na celu przybliżenie kluczowych tez teoretycznych na temat podziałów społeczno-politycznych, które warto mieć na uwadze, organizując badania nad podziałami, oraz które powinny być uwzględniane w procesie formułowania teorii politycznych. Pozostaje mieć nadzieję, że to, co zostało w tym tekście zaprezentowane, będzie stanowiło inspirujący punkt wyjścia do różnorodnych pogłębionych badań politologicznych nad podziałami społeczno-politycznymi, które przecież w Polsce i na świecie mają niezwykle bogatą tradycję.

\section{Bibliografia:}

Bartolini, S., Mair, P. (1990). Identity, Competition and Electoral Availability: The Stabilization of European Electorates, 1885-1985. Cambridge: Cambridge University Press.

Bojarowicz, T. (2005). New Axes of Political Cleavages in Poland after 2005. Regional Formation and Development Studies, 1(21), 6-15.

Bojarowicz, T. (2018). Koncepcje ideowe partii politycznych a podziały społeczno-polityczne w III RP. W: G. Radomski, M. Strzelecki, K. Sopolińska (red.). Rzeczpospolita w koncepcjach polskich partii i środowisk politycznych XX i XXI wieku (s. 169-180). Toruń: Wydawnictwo Naukowe Uniwersytetu Mikołaja Kopernika.

Bornschier, S. (2007). Social Structure, Collective Identities, and Patterns of Conflict in Party Systems: Conceptualizing the Formation and Perpetuation of Cleavages. Working Paper for ECPR Workshop Politicising Socio-Cultural Structures: Elite and Mass Perspectives on Cleavages. DOI: 10.5167/uzh-3048.

Bornschier, S. (2009). Cleavage Politics in Old and New Democracies. Living Reviews in Democracy, 1, 1-13.

Bornschier, S. (2010). Cleavage Politics and the Populist Right: The New Cultural Conflict in Western Europe. Philadelphia: Temple University Press.

Cześnik, M., Grabowska, M. (2017). Popękane polskie społeczeństwo jako pole badawcze - dane, fakty, mity. Przeglad Socjologiczny, 66, 9-43.

Cześnik, M., Kotnarowski, M. (2011). Nowy wymiar politycznego współzawodnictwa: Polska solidarna versus Polska liberalna. Studia Polityczne, 27, 129-158.

Deegan-Krause, K. (2010). Nowe wymiary rozłamu politycznego. W: H.-D. Klingemann (red.). Zachowania polityczne 2 (s. 130-155). Warszawa: Wydawnictwo Naukowe PWN.

Enyedi, Z. (2005). The Role of Agency in Cleavage Formation. European Journal of Political Research, 44, 697-720. DOI: 10.1111/j.1475-6765.2005.00244.x.

Enyedi, Z. (2008). The Social and Attitudinal Basis of Political Parties: Cleavage Politics Revisited. European Review, 16(3), 287-304. DOI: 10.1017/S1062798708000264.

Evans, G. (2006). The Social Bases of Political Divisions in Post-Communist Eastern Europe. Annual Review of Sociology, 32, 245-270.

Górka, M. (2009). Kształtowanie się politycznych biegunów w polskim systemie partyjnym w latach 2005-2007. Politeja, 12, 57-74. 
Grabowska, M. (2004). Podziat postkomunistyczny. Spoteczne podstawy polityki w Polsce po 1989 roku. Warszawa: Wydawnictwo Naukowe Scholar.

Grabowska, M., Szawiel, T. (2003). Budowanie demokracji. Podziaty spoteczne, partie polityczne i spoteczeństwo obywatelskie w postkomunistycznej Polsce. Warszawa: Wydawnictwo Naukowe PWN.

Heidar, K. (2003). Parties and Cleavages in the European Political Space. ARENA Working Paper, WP 03/7.

Klepka, R. (2013). Podziały elit politycznych jako kryterium periodyzacji okresu III RP. W: J. Sielski, J. Mizgalski, J. Jajduk (red.). Polska między przesztościa i przysztościa. Ksiegga jubileuszowa dedykowana Profesorowi dr. hab. Janowi Walczakowi (s. 51-69). Częstochowa: Wydawnictwo im. S. Podobińskiego Akademii im. Jana Długosza.

Knutsen, O., Scarbrough, E. (1995). Cleavage Politics. W: J. van Deth, E. Scarbrough (red.). The Impact of Values (s. 492-523). Oxford: Oxford University Press.

Kriesi, H. (1998). The Transformation of Cleavage Politics. The 1997 Stein Rokkan Lecture. European Journal of Political Research, 33, 165-185.

Lipset, S.M. (1967). Party Systems and Voter Alignments: Cross-National Perspectives. New York: The Free Press.

Lipset, S.M., Rokkan, S. (1990). Cleavage Structures, Party Systems, and Voter Alignments. W: P. Mair (red.). The West European Party System. Oxford: Oxford University Press. Alternatywnie: Lipset, S.M., Rokkan S. (1995). Osie podziałów, systemy partyjne oraz afiliacje wyborców. W: J. Szczupaczyński (red.). Wtadza i spoteczeństwo I (s. 89-122). Warszawa: Wydawnictwo Naukowe Scholar.

Markowski, R. (2000). Rozłamy socjopolityczne: o zamyśle klasyków, o tym, jak ich rozumiano, poprawiano i testowano. Studia Polityczne, 10, 7-43.

Markowski, R. (2006). Wybory 2005 - chaos czy restrukturyzacja systemu partyjnego. W: I. Słodkowska, M. Dołbakowska (red.). Wybory 2005. Partie i ich programy (s. 9-19). Warszawa: ISP PAN.

Markowski, R. (2011). Wybory parlamentarne 2007 roku - ciągły zamęt czy utrwalenie nowego rozłamu? Studia Polityczne, 27, 109-127.

Markowski, R. (2016). The Polish Parliamentary Election of 2015: A Free and Fair Election that Results in Unfair Political Consequences. West European Politics, 39(6), 1311-1322. DOI: 10.1080/01402382.2016.1177305.

Markowski, R., Stanley, B. (2016). Rozłamy socjopolityczne w Polsce: iluzja czy rzeczywistość? Studia Socjologiczne, 4, 17-40.

Obacz, P. (2017). Podział społeczno-polityczny w Polsce - wymiar aksjologiczny. Istota, konsekwencje, prognozy. W: E. Starzyńska-Kościuszko (red.). Wartości i wartościowanie we wspótczesnej humanistyce. I: perspektywa filozoficzna (s. 201-211). Olsztyn: Centrum Badań Europy Wschodniej Uniwersytetu Warmińsko-Mazurskiego w Olsztynie.

Obacz, P. (2018a). Analiza sytuacyjna polskiego życia politycznego i społeczeństwa. Kilka uwag na temat wielości źródeł władzy w Polsce. W: A. Pytka, K. Maciąg (red.). Rozważania na temat kondycji polskiego spoteczeństwa (s. 14-23). Lublin: Wydawnictwo Naukowe Tygiel. 
Obacz, P. (2018b). Podziat „Polska solidarna - Polska liberalna” w świetle wybranych koncepcji pluralizmu politycznego. Kraków: Wydawnictwo Libron.

Obacz, P. (2020). Identyfikowanie śladów polityki rozłamowej w dokumentach ideowo-programowych partii politycznych: założenia metodologiczno-teoretyczne. Historia i Polityka, 31(38), 89-101. DOI: 10.12775/HiP.2020.006.

Obacz, P. (2021). Podział społeczno-polityczny w Polsce i jego przejawy w parlamentarnej kampanii wyborczej 2019 roku. W: P. Borowiec, A. Tyszkiewicz (red.). Kampania wyborcza 2019 roku. Kraków: Wydawnictwo Uniwersytetu Jagiellońskiego.

Sitter, N. (2002). Cleavages, Party Strategy and Party System Change in Europe, East and West. Perspectives on European Politics and Society, 3(3), 425-451.

Studia Politologiczne, 2013, 29: tam zwł. artykuły A. Bejmy, M. Białousa, W. Łukowskiego, I. Sadowskiego. 